\title{
Differences in levels of heterozygosity in populations of the common gudgeon (Gobio gobio, Cyprinidae) among adjacent drainages in Central Europe: an effect of postglacial range dynamics?
}

\author{
A Schreiber \\ Institute of Zoology, University of Heidelberg, Heidelberg, Germany
}

Twenty-nine allozyme loci analyzed in 295 common gudgeons (Gobio gobio) from the Rhine, the upper Danube and the Elbe river systems revealed variability measures of $P=$ $0.590, H_{e}=0.066$, and $G_{S T}=0.1415$. Gene flow was estimated at $N_{e} m=1.88$ over 223 river $\mathrm{km}$ in the Danube basin, and at $N_{e} m=1.96$ over 300 river $\mathrm{km}$ in the Rhine system. Isolation-by-distance was not observed. Danubian gudgeons proved significantly more heterozygous $\left(H_{e}=0.106\right)$ than those from the Rhine $\left(H_{e}=0.057\right)$ or the Elbe drainages $\left(H_{e}=0.029\right)$. Nine polymorphic enzymes contributed to this difference, which probably indicates dispersal bottlenecking of the postglacial immigrants into the Atlantic drainages of the study area. Refugial bottlenecking of gudgeons from Atlantic drainages in a Pleistocene refuge located in oceanic northwest Europe also seems possible. Slightly deeper genetic lineages in the Danube $\left(G_{S T}=0.0859\right)$ than in the Rhine $\left(G_{S T}=0.0793\right)$ agree with this explanation, as does the greater mean genetic distance among pairs of population samples from the Danube $(D=0.0138)$ than from the Rhine $(D=0.0054)$. A genetic distance of $D=0.0085$ separated Rhenish and Danubian gudgeons.

Heredity (2002) 89, 163-170. doi:10.1038/sj.hdy.6800109

Keywords: phylogeography; Gobio gobio; Cyprinidae; range dynamics; allozymes

\section{Introduction}

Pleistocene glaciations have complicated the zoogeography of the Holarctic fish fauna, by the retreat of thermophilous species to southern refugial areas at the onset of each glaciation phase, and their eventual recolonization following deglaciation (Reinig, 1937; Thienemann, 1950; Banarescu, 1991). These range dynamics of the Quaternary and early Holocene imply the evolution of zones secondary population contact, which are of interest for genetics and taxonomy, and for fisheries or species conservation management. A number of genetic studies have reconstructed postglacial recolonization routes, and zones of population hybridization, of European freshwater fish (eg, Riffel and Schreiber, 1995; Riffel et al, 1995; Durand et al, 1999; Nesbo et al, 1999; Koskinen et al, 2000). Another genetic aspect of this range dynamics has received little attention from fish biologists. The reduction of the population genetic variability during range expansion by dispersal bottlenecking and genetic drift has, in many animal groups, created a continentwide biogeographical pattern of southern richness and northern purity (Rensch, 1939; Hewitt, 1999). Northern species may, however, display the reverse pattern of what is sometimes a pronounced homozygosity in their extreme southern populations (Schreiber et al, 1996). First

Correspondence: A Schreiber, Institute of Zoology, University of Heidelberg, Im Neuenheimer Feld 230, D-169120 Heidelberg, Germany. E-mail: arnd.schreiber@urz.uni-heidelberg.de

Received 12 November 2001; accepted 23 April 2002 observed by Reinig (1938), dispersal bottlenecking also holds true for freshwater fish. The 42 Holarctic fish species reviewed by Bernatchez and Wilson (1998) revealed significantly reduced levels of mtDNA nucleotide diversity with geographical latitude, and northern species/ populations that have immigrated into previously glaciated rivers are, as a rule, genetically more uniform than those from glacial refuges.

In Europe the watersheds of rivers draining into the Atlantic and into the Mediterranean Sea or the Black Sea could be of particular importance in this regard, because they represent a major secondary contact zone of fish invading from different refuges (Riffel and Schreiber, 1995; Schreiber et al, 1998). In each glacial cycle fish could have avoided the periglacial upper Danube, which was influenced by the melting waters and moraine gravel of the nearby Alpine glaciers, by descending downstream to the Black Sea basin which has retained temperate-zone conditions for limnofauna throughout the Pleistocene. They were able to recolonize, upon deglaciation, along the same route without meeting physical obstacles (Thienemann, 1950). By contrast, the northwardly directed Rhine retained only cold-adapted fish after the Würm glaciation at 10000 years b.p. (Torke, 1998). Immigrants had to be able to traverse marine waters, or to surmount the watersheds to the south (Rhône, Danube) or the east (Elbe). The upper Danube is inhabited by 50 fish species, including endemics, but the adjacent Rhine, which offers a similar range of biotopes, has only 42 species, none of them endemic (Berg et al, 1989). The relative species richness is due to several late postglacial invaders 
which have reached the upper Danube but not (yet) the Rhine system (Thienemann, 1941). At the population genetic level, comparisons of Rhenish and Danubian fish have been confined to trout (Riffel et al, 1995), sculpin (Riffel and Schreiber, 1995), chub (Hänfling and Brandl, 1998), and grayling (Gross et al, 2001), ie to species which have survived the Würm glaciation in Central Europe (Torke, 1998). These are unsuitable candidates to investigate dispersal bottlenecking. The present study maps the allozyme variability of the common gudgeon (Gobio gobio) which is absent from the very rich late Pleistocene record of fossil fish in the Rhine/Danube contact area (Torke, 1998). It is shown that the gudgeon populations from two Atlantic drainages, ie the Rhine and the Elbe, contain significantly reduced levels of allozyme heterozygosity when compared with gudgeons from the Danube. It is suggested that this difference can be understood as the effect of postglacial range dynamics.

Gobio gobio is a taxonomically difficult species which shows an extraordinary phenotypic diversity, but the validity of many of its nominal subspecies continues to be controversial (Banarescu and Nalbant, 1973; Banarescu et $a l, 1999)$. Therefore, genetic data are of interest to identify population units for conservation management. Lotic (rheophilic) morphotypes have a longer tail peduncle, more deeply forked caudal fins, longer paired fins and barbels, and are darker than the lentic (limnophilic) stillwater forms from the same general area, which have a higher body shape and rounded caudal fins (Banarescu et al, 1999). The heritabillity of this morphotypic dichotomy is uncertain. Gudgeons are unattractive to the fishing industry or for sportsfishing, and therefore the species is neither hatchery-bred nor stocked anywhere in the study area, or likely to have been in the past, at any significant level. Its genetic population structure should reflect natural patterns rather than the consequence of human management.

\section{Materials and methods}

\section{Populations}

Gobio gobio were collected by electrofishing at 17 localities, chiefly in 1998/1999 (Table 1, Figure 1). Most local samples were acquired from within a few $100 \mathrm{~m}$ of river length, but two of them were assembled over tens of river $\mathrm{km}$, and at two sampling dates each, ie Murr ( $n=24$ in 1996, and $n=25$ in spring 1999) and Nette ( $n$ $=4$ in the early 1990s, and $n=26$ in 1999). The controversial species identity of gudgeons from the Danube (Berg et al, 1989) was determined by inspecting the morphological characters summarized by Wanzenböck et al (1989) and Banarescu et al (1999). Their zymograms were also compared with those of confirmed reference specimens of the whitefin gudgeon (G. albipinnatus), the stone gudgeon (G. uranoscopus), and the sand gudgeon (G. kessleri), to prevent the inclusion of misidentified specimens. Each gudgeon collected from the Rhine and the uppermost Danube river proved to be G. gobio. Records of G. albipinnatus were confined to the lower Isar river (Danube) and a small stream entering the Rott (InnDanube)

Technique

Allozymes were assayed from homogenized skeletal muscle and liver tissue (Table 2 ) in $1 \%$ agarose gels using
Table 1 Locations and sizes of 17 population samples of the common gudgeon (Gobio gobio) from the Rhine and Danube river systems

\begin{tabular}{llr}
\hline River system/Region & Collection sites & No. \\
\hline Rhine $(n=199)$ & & \\
Hochrhein & Rheinfelden (RHE) & 11 \\
Oberrhein & Istein (IST) & 10 \\
& Riegel (RIE) & 19 \\
Mittelrhein & Weschnitz (WES) & 7 \\
& Nette (NET) & 30 \\
Neckar & Stunzach (STU) & 14 \\
& Haigerloch/Rottenburg (ROT) & 11 \\
& Murr (MUR) & 49 \\
& Zaber (ZAB) & 21 \\
Main & Bühler/Kocher (BÜH) & 6 \\
& Gersprenz (GER) & 21 \\
Danube $(n=55)$ & & \\
uppermost Danube & Beuron (BEU) & 19 \\
& Neuburg (NEU) & 8 \\
Isar & Westernach/Rot (WEN) & 20 \\
\multirow{2}{*}{$(n=41)$} & Mühlbach (ISA) & 8 \\
Mittelelbe & & \\
& Oessau (OES) & 15 \\
& Gross-Rosenburg (ROS) & 26 \\
\hline
\end{tabular}

standard zymography (Harris and Hopkinson, 1976). The alleles were designated by their electrophoretic mobility in relation to the mobility of the most frequent variant which was defined as $100 \%$. Migration to the cathode is indicated by a negative sign.

\section{Statistics}

Diversity measures for entire drainages have been derived after pooling all specimens from the respective river systems. Genetic distances are unbiased standard distances (Nei, 1978). Hierarchical gene diversity analysis followed Chakraborty and Leimar (1987), and used unbiased esimates which weighted samples of varying size equally (Nei and Chesser, 1983). Chi-square tests of Hardy-Weinberg equilibrium used the sequential Bonferroni and the Yates corrections (Lessios, 1992). Heterogeneity analysis of genotype distibutions, or allele frequencies, followed Workman and Niswander (1970). Gene flow was estimated from gene diversity indices (Wright, 1951). Principal component analysis (PCA) was performed on the arcsine-transformed allele frequencies using the SSPS software package. The matrix correlation of geographical and genetic distances (Mantel, 1967) used NTSYS/PC 2.02f software (Rohlf, 1998), after data transformation to adjust the different scales of distance values (Sokal, 1979).

\section{Results}

\section{Genetic variability}

The electrophoretic screening of 29 inferred loci (Table 2) in 295 G. gobio from 17 collection sites in the Rhine, Elbe and Danube river systems (Table 1; Figure 1) revealed allelic variability in 12 enzyme systems representing 17 inferred loci, i.e. Gpi-1*, Gpi-2*, Pgm-2*, Pgd*, Me-2*, Aat$2^{*}$, Aat-3* Ada $^{*}, \mathrm{Mpi}^{*}, \mathrm{Sod}^{*}, \mathrm{Mdh}-3^{*}, \mathrm{Mdh}-4^{*}, \mathrm{Ck}-\mathrm{1}^{*}, \mathrm{Ck}-2^{*}$, 

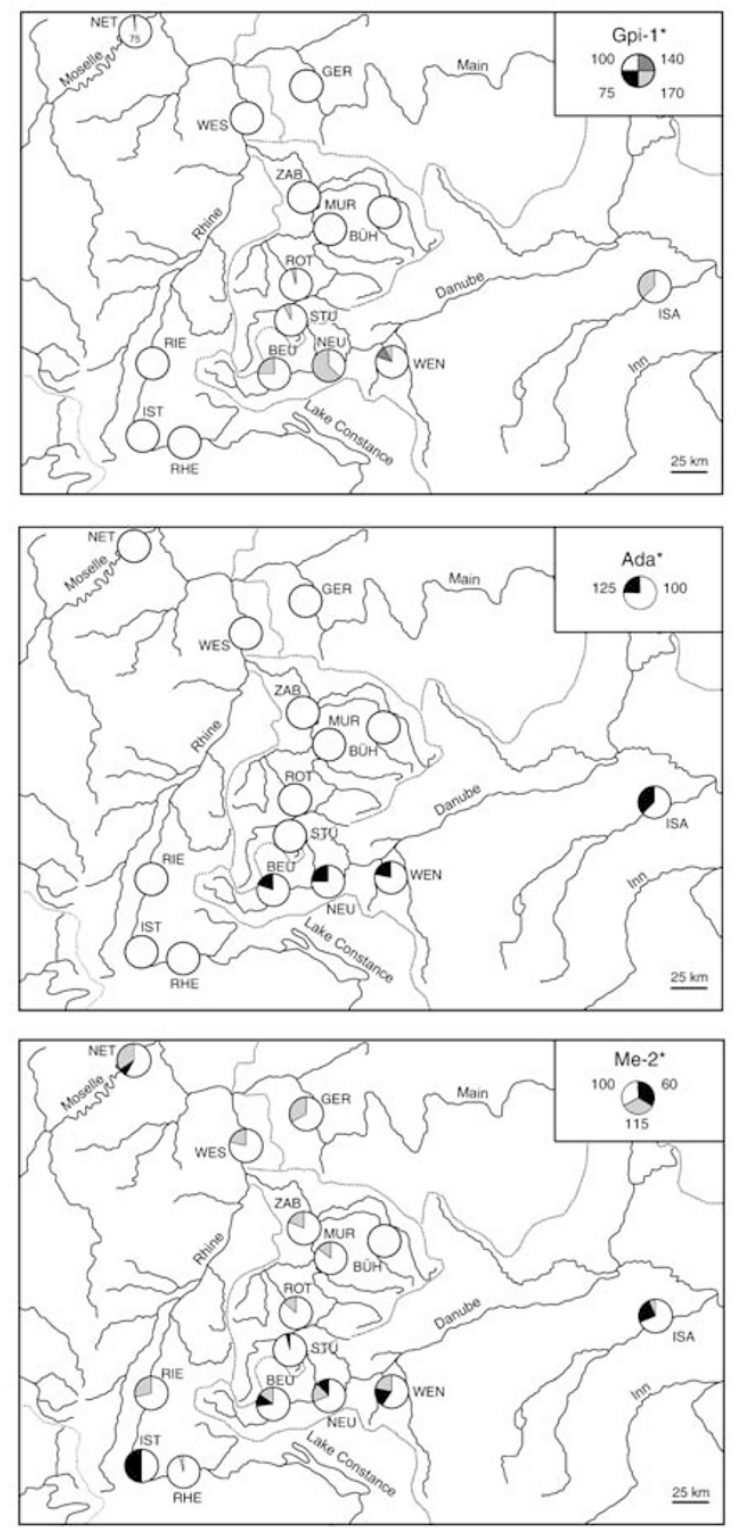

Figure 1 Collection sites of common gudgeons (Gobio gobio) in southern Germany, and the geographical allele distribution of the polymorphic loci Gpi-1*, Ada*, and Me-2*. Major watersheds are indicated by stippled lines.

Ck-3* Dia*, and $L d h-1^{*}$, and 12 monomorphic loci, ie Aat$1^{*}, \mathrm{Me}-1^{*}, I d h-1^{*}, I d h-2^{*}, \mathrm{Fh}^{*}, \mathrm{Acp}^{*}, \mathrm{Glo}{ }^{*}, \mathrm{Ck}-4^{*}, \mathrm{Mdh}-1^{*}$, $M d h-2^{*}, C a^{*}$, and $L d h-2^{*}$. Fifty-four alleles were encountered in total. The allele frequencies are provided in the Appendix. Overall variability measures were $P=0.586$, $H_{o}=0.057, H_{e}=0.066$, and A.D. $=1.90$. Within each local population the allozymic genotypes conformed to HardyWeinberg propositions. A few exceptional cases were no longer statistically significant after applying sequential Bonferroni-correction for multiple testing.

\section{Geographical population structure}

The expected allozyme heterozygosity for the whole sample from the Rhine drainage $(n=199)$ was $H_{e}=0.057$, for the 41 gudgeons from two sites in the Elbe (Mulde) system $H_{e}=0.029$, and for the 55 from four Danubian sites,
$H_{e}=0.106$. The expected heterozygosity of every popu-

lation sample from the Rhine fell short of the value for every sample from the Danube (Table 3). Nine polymorphic loci (Table 4) contributed to this difference which is statistically significant (Mann-Whitney test; $P<0.005$ ). Pie charts depicting the allele distrubution at three polymorphic loci, Gpi-1*, $A d a^{*}$, and $\mathrm{Me}-2^{*}$, illustrate this geographic pattern graphically (Figure 1 ).

Genetic differentiation between the 17 population samples accounted for $14.15 \%$ of the total variation $\left(G_{S T}\right.$ $=0.1415)$, the remainder $(85.85 \%)$ was contributed by the variability of individuals within the collection sites. The loci Ck-1* Gpi-1*, Ada* and Aat-2* distinguished gudgeon populations from the different river basins best, ie $F_{S T}=$ $0.3147\left(C k-1^{*}\right), F_{S T}=0.3082\left(G p i-1^{*}\right), F_{S T}=0.2045\left(\right.$ Ada $\left.{ }^{*}\right)$, and $F_{S T}=0.1866($ Aat-2*). Hierarchical gene diversity analysis partitioned the spatial fraction of genetic variability into a component introduced by the three drainages of the Rhine, the Elbe, and the Danube rivers $\left(\mathrm{G}_{\mathrm{CG}}=\right.$ 0.0863 ), and into a variance component contained in these three groupings $\left(\mathrm{G}_{\mathrm{SG}}=0.0552\right)$. The Danubian gudgeons comprise slightly deeper genetic lineages $\left(G_{S T}=0.0859\right)$ than their conspecifics from the Rhine system $\left(G_{S T}=\right.$ 0.0793). A mean unbiased Nei distance of $D=0.0138$ separated pairs of population samples from the Danube basin, and $D=0.0054$ those from the Rhine system. The genetic distance across the Rhine/Danube watershed was $D=0.0085$. Principal component analysis of allele frequencies (Figure 2) confirms a tighter population cluster from the Rhine system which groups apart from the more widely scattered Danubian samples.

Heterogeneity analyses of genotype distibutions or of allele frequencies, testing for deviations from hypothetical metapopulation expectations, did not reveal significant differentiation within the Rhine, the Danube, or the Elbe river systems. Rhenish and Danubian gudgeons differed, after Bonferroni correction for multiple testing, in the genotype distributions of three polymorphisms, Rhenish and Elbian samples in three, and Danubian and Elbian samples in five polymorphic systems (Table 5). Isolation-by-distance was not revealed by Mantel's matrix correlation of geographical and genetic distances for gudgeons from the Rhine system ( $r=0.3252 ; P=0.27$ in a permutation test of 1000 runs) or the upper Danube ( $r=0.9312 ; P=0.25$ after 1000 permutation test runs), but the correlation coefficient for the Danubian population was markedly higher. The population samples were kept cohesive by an estimated gene flow of $N_{e} m=1.96$ in the Rhine (mean geographical distance among samples: 325 river $\mathrm{km}$ ), and of $N_{e} m=1.88$ in the Danube system (mean distance: 223 river $\mathrm{km}$ ).

\section{Discussion}

\section{Allozyme variability in perspective}

The heterozygosity of the common gudgeon from the Danube, $H_{e}=0.106$, surpassed the heterozygosity estimates for other fish and cyclostome species investigated in the Rhine/Danube contact area by the same technique, ie the stone loach Barbatula barbatula $\left(H_{e}=0.082\right.$; Schreiber, submitted), the river lamprey Lampetra fluviatilis $\left(H_{e}\right.$ = 0.066; Schreiber and Engelhorn, 1998), the soufie Leuciscus souffia $\left(H_{e}=0.061\right.$; Schreiber, submitted), the brook lamprey Lampetra planeri $\left(H_{e}=0.046\right.$ in the Rhine basin; 
Table 2 Enyzmes and inferred genetic loci screened electrophoretically in liver (l) or skeletal muscle (m) tissue of Gobio gobio

\begin{tabular}{|c|c|c|}
\hline Enyzme & Tissue & Locus \\
\hline Acid phosphatase (E.C. 3.1.3.2) & $1, \mathrm{~m}$ & $A c p^{*}$ \\
\hline Adenosine desaminase (E.C. 3.5.4.4) & $\mathrm{m}$ & Ada* \\
\hline Aspartate aminotransferase (E.C. 2.6.1.1) & $1, \mathrm{~m}$ & Aat $-1^{*}$, Aat2* Aat $-3^{*}$ \\
\hline Carbonic anhydrase & $1, \mathrm{~m}$ & $C a^{*}$ \\
\hline Creatine kinase (E.C. 2.7.3.2) & $\mathrm{m}$ & $C k-1^{*}, C k-2^{*}, C k-3^{*}, C k-4^{*}$ \\
\hline NADH Diaphorase (E.C. 1.6.2.2) & $\mathrm{m}$ & Dia* \\
\hline Fumarate dehydrogenase (E.C. 4.2.1.2) & $\mathrm{m}$ & $F h^{*}$ \\
\hline \multirow[t]{2}{*}{ Glucose-6-phosphate isomerase (E.C. 5.3.1.9) } & $\mathrm{m} \mathrm{l}$ & Gpi-1* \\
\hline & $\mathrm{m}$ & Gpi-2* \\
\hline Isocitrate dehydrogenase (E.C. 1.1.1.42) & $\mathrm{m}$ & $I d h-1^{*}, I d h-2^{*}$ \\
\hline Lactate dehydrogenase (E.C. 1.1.1.27) & $\mathrm{m}$ & $L d h-1^{*}, L d h-2^{*}$ \\
\hline Lactoyl glutathione lyase (E.C. 4.4.1.5) & $1, \mathrm{~m}$ & $G l 0^{*}$ \\
\hline \multirow[t]{2}{*}{ Malate dehydrogenase (E.C. 1.1.1.37) } & $\mathrm{m}$ & $M d h-1^{*}, M d h-3^{*}, M d h-4^{*}$ \\
\hline & 1 & $M d h-2^{*}$ \\
\hline Malic enzyme (E.C. 1.1.1.40) & $\mathrm{m}$ & $M e-1^{*}, M e-2^{*}$ \\
\hline Mannose-phosphate isomerase (E.C. 5.3.1.8) & $1, \mathrm{~m}$ & $M p i^{*}$ \\
\hline Phosphoglucomutase (E.C. 5.4.2.2) & $1, \mathrm{~m}$ & $\operatorname{Pgm}^{*}$ \\
\hline 6-Phosphogluconate dehydrogenase (E.C. 1.1.1.44) & $1, \mathrm{~m}$ & $P g d^{*}$ \\
\hline Superoxide dismutase (E.C. 1.15.1.1) & $1, \mathrm{~m}$ & Sod ${ }^{*}$ \\
\hline
\end{tabular}

Table 3 Estimates of observed $\left(H_{o}\right)$ and expected $\left(H_{e}\right)$ heterozygosity, percentages of polymorphic loci $(\mathrm{P})$, and allele numbers per locus (A.D.) in population samples of Gobio gobio (cf. Table 1)

\begin{tabular}{lcccc}
\hline Population sample & $H_{o}$ & $H_{\mathbf{e}}$ & $P$ & $A . D$. \\
\hline STU & 0.050 & 0.049 & 0.210 & 1.21 \\
MUR & 0.047 & 0.047 & 0.140 & 1.21 \\
ZAB & 0.066 & 0.060 & 0.240 & 1.24 \\
RÖ & 0.057 & 0.056 & 0.210 & 1.21 \\
BÜH & 0.017 & 0.015 & 0.070 & 1.07 \\
RHE & 0.053 & 0.045 & 0.170 & 1.17 \\
IST & 0.073 & 0.050 & 0.172 & 1.17 \\
NET & 0.062 & 0.067 & 0.210 & 1.24 \\
WES & 0.039 & 0.051 & 0.170 & 1.21 \\
RIE & 0.053 & 0.061 & 0.240 & 1.28 \\
GER & 0.043 & 0.043 & 0.170 & 1.17 \\
Rhine system & 0.053 & 0.057 & 0.480 & 1.72 \\
WEN & & & & \\
BEU & 0.080 & 0.089 & 0.280 & 1.38 \\
NEU & 0.116 & 0.100 & 0.380 & 1.41 \\
ISA & 0.086 & 0.074 & 0.210 & 1.24 \\
Danube system & 0.113 & 0.106 & 0.240 & 1.31 \\
OES & 0.098 & 0.106 & 0.410 & 1.10 \\
ROS & & & & \\
Elbe system & 0.016 & 0.020 & 0.070 & 1.07 \\
\hline
\end{tabular}

Schreiber and Engelhorn, 1998), the brown trout Salmo trutta $\left(H_{e}=0.038\right.$; Riffel et al, 1995), the Ukrainian brook lamprey Eudontomyzon mariae $\left(H_{e}=0.027\right.$; Schreiber and Engelhorn, 1998), and the sculpin Cottus gobio $\left(H_{e}=0.017\right.$; Riffel and Schreiber, 1995). Accordingly, the heterozygosity of Danubian gudgeons matches the extraordinary phenotype diversity (body proportions, fin shape, pigmentation, and arrangement of scales) of Gobio gobio (Banarescu and Nalbant, 1973; Banarescu et al, 1999).

The gene diversity index of the common gudgeon, $G_{S T}$ $=0.1415$, was fairly low, and gene flow accordingly high,
Table 4 The estimates of observed heterozygosity for nine enzyme polymorphisms in population samples of Gobio gobio from the Rhine $\left(H_{\mathrm{o}}\right)$ and from the Danube drainages $\left(H_{\mathrm{o}}\right)$, and the quotients of these values per locus. Data for the only two population samples from the Elbe basin are omitted

\begin{tabular}{|c|c|c|c|}
\hline & $H_{\mathrm{o}}^{\mathrm{R}}$ & $H_{\mathrm{o}}^{\mathrm{D}}$ & $H_{\mathrm{o}}^{\mathrm{R}} / H_{\mathrm{o}}^{\mathrm{D}}$ \\
\hline Gpi-1* & 0.020 & 0.375 & $5.3 \%$ \\
\hline$P g d^{*}$ & 0.452 & 0.574 & $78.8 \%$ \\
\hline$M e^{*}$ & 0.322 & 0.615 & $52.4 \%$ \\
\hline$A d a^{*}$ & 0.000 & 0.404 & - \\
\hline$M p i^{*}$ & 0.000 & 0.096 & _- \\
\hline$L d h^{*}$ & 0.000 & 0.054 & - \\
\hline Sod ${ }^{*}$ & 0.015 & 0.054 & $27.8 \%$ \\
\hline$C k-1^{*}$ & 0.015 & 0.296 & $5.1 \%$ \\
\hline$M d h-4^{*}$ & 0.005 & 0.018 & $27.8 \%$ \\
\hline
\end{tabular}

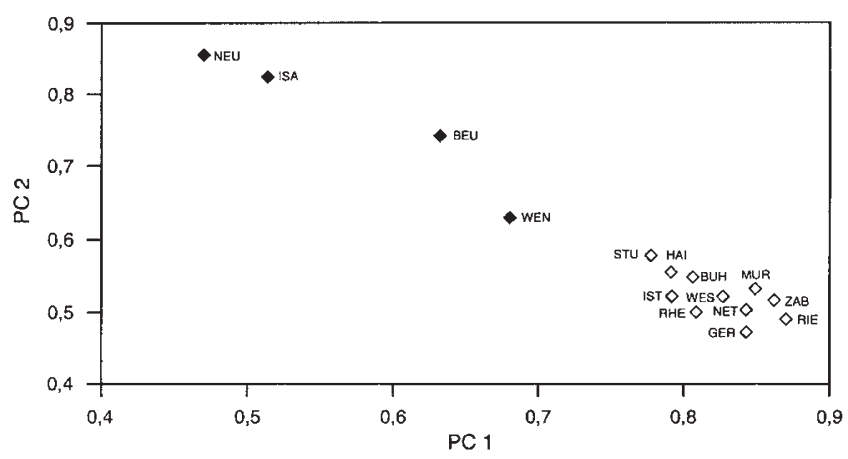

Figure 2 Principal component analysis of allozymic allele frequencies in population samples of Gobio gobio. In the plot of factors PC1 and PC 2, which explain $92.8 \%$ and $2.9 \%$ of the total variance respectively, the Danubian population samples are represented by black, and Rhenish samples by open, diamonds. For abbreviations, see Table 1. 
Table 5 Polymorphic enzyme loci showing significantly different genotype distributions between population samples Gobio gobio from the Rhine, the Elbe, and the Danube drainage systems. For the statistical test, see Material and methods

\begin{tabular}{|c|c|c|}
\hline $\begin{array}{l}\text { Pairs of } \\
\text { population } \\
\text { samples }\end{array}$ & Locus & Significance \\
\hline Rhine/Danube & $\begin{array}{l}G p i-1^{*} \\
M e^{*} \\
C k-1^{*}\end{array}$ & $\begin{array}{l}X_{\mathrm{df}=1}^{2}=87.365 ; \text { Yates }=0.5 ; P<0.0002 \\
X_{\mathrm{df}=2}^{2}=19.735 ; \text { Yates }=0 ; P<0.001 \\
X_{\mathrm{df}=1}^{2}=71.821 ; \text { Yates }=0.5 ; P<0.0002\end{array}$ \\
\hline Rhine/Elbe & $\begin{array}{l}\text { Me* } \\
\text { Pgm-2* } \\
\text { Aat }-2^{*}\end{array}$ & $\begin{array}{l}X_{\mathrm{df}=2}^{2}=32.276 ; \text { Yates }=0.0 ; P<0.0002 \\
X_{\mathrm{df}=1}^{2}=30.766 ; \text { Yates }=0.5 ; P<0002 \\
X_{\mathrm{df}=1}^{2}=8.255 ; \text { Yates }=0.5 ; P<0.05\end{array}$ \\
\hline Danube/Elbe & $\begin{array}{l}\text { Gpi-1* } \\
\text { Ck-1* } \\
\text { Pgm-2* } \\
\text { Ada* } \\
\text { Aat-2* }\end{array}$ & $\begin{array}{l}X_{\mathrm{df}=1}^{2}=27.393 ; \text { Yates } 0.5 ; P<0.0002 \\
X_{\mathrm{df}=2}^{2}=18.851 ; \text { Yates }=0.0 ; P<0.001 \\
X_{\mathrm{df}=1}^{2}=16.458 ; \text { Yates }=0.5 ; P<0.001 \\
X_{\mathrm{df}=1}^{2}=24.294 ; \text { Yates }=0.5 ; P<0.0002 \\
X_{\mathrm{df}=1}^{2}=11.094 ; \text { Yates }=0.5 ; P=0.01\end{array}$ \\
\hline
\end{tabular}

when compared with values of $G_{S T}=0.8489$ for sculpins (Riffel and Schreiber, 1995), $G_{S T}=0.5473$ for the Ukrainian brook lamprey (Schreiber and Engelhorn, 1998), $G_{S T}$ $=0.4629$ for the brook lamprey in the Rhine (Schreiber and Engelhorn, 1998), $G_{S T}=0.2977$ for brown trout (Riffel et al, 1995), and $G_{S T}=0.1965$ for the stone loach (Schreiber, submitted). Only the values of $G_{S T}=0.1240$ for the soufie (Schreiber, submitted), and of $G_{S T}=0.0537$ for the river lamprey (Schreiber and Engelhorn, 1998) were lower, but merely two relict stocks of the menaced soufie could be compared, and the river lamprey is an anadromous species whose migration distances surpassed the sampling area for allozyme analysis. Gudgeons are not known to be migratory (Banarescu et al, 1999), but their biotope tolerance permits their continuous and abundant occurrence throughout the Rhine and the upper Danube systems. Their ova are said to be sticky (Banarescu et al, 1999). Lotic and lentic morphotypes (Banarescu et al, 1999), though not specifically determined, were included in some population samples at least, but this morphotypic diversity was not reflected by any allozymic measure.

\section{Patchwork of geographical populations with different} levels of heterozygosity

Significantly different heterozyosity estimates distinguished the common gudgeons of the Rhine from those of the Danube. These populations do not appear to differ in aspects of their lifestyle which are relevant for gene flow, nor are they likely to import genetic variability by hybridizing with another cyprinid species (cf. Schreiber and Engelhorn, 1998). Since nine polymorphic loci, which represent very different enzymatic functions, contribute to the different heteroyzgosity estimates, natural selection favouring, or diminishing, the variability of certain functional gene systems does not explain this difference among the drainages. Recent bottlenecking of the actual population is equally unlikely, because transect counts have revealed huge numbers (perhaps $10^{7}$, or more) of gudgeons spread throughout the whole Rhine system (Köhler, 1992). Not even the climax phase of water pollution (1950-1980) can have caused a real bottle- neck situation for this abundant population, because $G$.

gobio is a very adaptable biotope generalist able to resist the organic and thermal pollution of river waters (Penaz et al, 1999). It survived in many tributaries of the Rhine in large numbers throughout the 20th century. Thus genetic drift caused by a population bottleneck in the more remote history of this species is the most likely explanation left for the different levels of heterozygosity among the Rhine/Elbe and Danube drainages.

Thienemann (1941) included the common gudgeon in his zoogeographical category of the 'mixed European glacial fish community'. This was meant to indicate that the species has probably survived the Würm glaciation in Central or northern Europe, though not close to the glaciated areas (Thienemann, 1941). Gudgeons are absent from the very rich record of fossil Pleistocene fishes in the study area (Torke, 1989) which was heavily influenced by the nearby prealpine glacier front (melting water, flow regime, moraine sediment freights). Most probably the southern Rhine and the upper Danube have been (re)colonized by gudgeons in the early Holocene. Common gudgeons are eurythermous summer spawners, remaining active throughout winter, and are able to glue their eggs to unvegetated stones. They are thought to have reached Sweden in the Ancylus period at 8000 years b.p. (Thienemann, 1941), but they have not colonized countries located as far north as Norway or Scotland. The glacial refuge in the lower Danube is inhabited by four gudgeon species (Banarescu and Nalbant, 1973), and might have supplied the invaders of the Danubian part of the present study area. By contrast, the Rhine as a northwardly directed river system might have been reached by immigrants which crossed at least one, or perhaps several, watersheds, depending on the colonization route. Several freshwater fish species have probably reached the Rhine over the flat lowland watersheds in the northeast German/Polish/Russian plain, or over the Rhône/Rhine watershed from a southwestern refuge (Thienemann, 1950). The common gudgeon is able to tolerate brackish waters, perhaps permitting a marine pathway along the coast too.

The study area may be inhabited by two different gudgeon subspecies (Banarescu and Nalbant, 1973; Banarescu et al, 1999) which would indicate double immigration from two Würm refuges. In that case, refugial bottlenecking in a northwest European refuge, rather than dispersal bottlenecking, would account for the reduced heterozygosity in Atlantic drainages. The nominotypical subspecies G. g. gobio was described from a river in England which had coalesced with the Rhine system during the Würm glaciation, and which is located in the British Isles today. This putative refugial stock could have easily recolonized the southern Rhine system following deglaciation of the northern prealpine forelands, but only before England became sequestered from the European mainland during the Ancylus period. There is no reason to doubt that the gudgeons in the upper Danube experience gene flow from their conspecifics in the lower Danube which likely represent the phylogeographic stem population. G. g. obtusirostris was described from a type specimen caught in the Isar river, and may be found throughout the upper Danube (Banarescu et al, 1999). Both subspecies mentioned differ in head and snout lengths, the density and arrangement of breast scales, and eye diameter, but their validity is contro- 
versial (review: Banarescu et al, 19991). They seem to intergrade in southwest Germany (von Siebold, 1863). Heuschmann (1962) and Banarescu et al (1999) lumped the common gudgeons from the Rhine and the upper Danube into the subspecies G. g. gobio, but they recognized certain morphological differences among geographical stocks. In connection with the present allozymic evidence of different levels of heterozygosity, these weak phenotypic differences could support the dual colonization of the study area from two different Würm refuges, but they do not prove this.

Dispersal or refugial bottlenecking has been observed in several organisms to reduce the level of genetic variability of range-expanding terminal populations (Reinig, 1938; Rensch, 1939; Schreiber et al, 1996; Fakler, 1999; Hewitt, 1999). In fish, a review of 42 Holarctic species revealed the macrogeographical pattern that populations in previously glaciated river basins of the northern hemisphere contained less genetic variability, and comprised shallower genetic lineages, than those in continuously unglaciated ice age refugia (Bernatchez and Wilson, 1998). Although each crossing of a watershed may affect the gene pool of an expanding fish by founder effects and rapid population growth from a narrow genetic basis in the new, unoccupied river system, this phenomenon has received comparatively little attention from evolutionary biologists. For gudgeons, only the continued genetic sampling in additional river systems will reveal the colonization routes, and the refugial areas, and thus permit the better understanding of mechanisms producing a regional patchwork of populations differing in genetic variability. To the ecologist, the different levels of heterozygosity in gudgeon populations from adjacent drainages offer the possibility to study the consequences, if any, of reduced levels of genetic variability on organismic fitness and adaptation. Common gudgeons from the Rhine and the Danube inhabit a wide variety of aquatic biotopes, and they appear equally able to cope with habitat destruction by river canalization and water pollution. However, a detailed comparative study of the means of these populations to adapt to natural environmental variance, and to anthropogenic perturbation of biotopes, appears to be of interest.

\section{Acknowledgements}

Dr R Berg (Fischereiforschungsstelle des Landes BadenWürttemberg, Langenargen) and his staff, Dr H Wedekind (Potsdam-Sacrow), and Dr J Schneider (Naturmuseum und Forschungsinstitut Senckenberg, Frankfurt) were helpful in collecting population samples of Gobio gobio, and Mr S Hoch (Fischereifachberatung der Regierung von Niederbayern, Landshut) provided G. albipinnatus. Dr R Bless (Bundesamt für Naturschutz, Bonn) provided reference specimens of G. uranoscopus and G. kessleri.

\section{References}

Banarescu P (1990). Zoogeography of Freshwaters. I. General Distribution and Dispersal of Freshwater Animals. Aula: Wiesbaden.

Banarescu P, Nalbant T (1973). Pisces, Teleostei, Cyprinidae (Gobioninae). Gruyter: Berlin.

Banarescu P, Soric V, Economidis P (1999). Gobio gobio (Agassiz, 1828). In: Banarescu P (ed) The Freshwater Fishes of Europe. Cyprinidae 2/I, Aula: Wiesbaden, pp 81-134.
Berg R, Blank S, Strubelt T (1989). Fische in Baden-Württemberg. Ministerium für ländlichen Raum: Stuttgart.

Bernatchez L, Wilson CC (1998). Comparative phylogeography of Nearctic and Palearctic fishes. Mol Ecol 7: 431-452.

Chakraborty R, Leimar O (1987). Genetic variation within a subdivided population. In: Ryman N, Utter F (eds) Population Genetics and Fisheries Management, UWP: Seattle, pp 89-120.

Durand JD, Persat H, Bouvet Y (1999). Phylogeography and postglacial dispersion of the chub (Leuciscus cephalus) in Europe. Mol Ecol 8: 989-997.

Fakler P (1999). Genetische Differenzierung des Eurasischen Dachses in Mittel-, Nord- und Nordwest-Europa. PhD Thesis, Heidelberg University.

Gross R, Kuhn R, Baars M (2001). Genetic differentiation of European grayling populations across the Main, Danube and Elbe drainages in Bavaria. J Fish Biol 58: 264-280.

Hänfling B, Brandl R (1998). Genetic and morphological variation in a common European cyprinid, Leuciscus cephalus, within and across Central European drainages. J Fish Biol 52: 706-715.

Harris H, Hopkinson DA (1976). Handbook of Enzyme Electrophoresis in Human Genetics. Elsevier: New York.

Heuschmann O (1962). Die Weißfische (Cyprinidae). In: Demoll R, Maier HN (eds) Handbuch der Binnenfischerei Mitteleuropas, Schweizerbart: Stuttgart, pp 23-199.

Hewitt GM (1999). Post-glacial recolonization of European biota. Biol J Linnean Soc 68: 87-112.

Köhler C (1992). Die Fischfauna des Rhein: Analyse der Artengemeinschaften sowie Daten zur Morphometrie und Meristik der vorkommenden Arten. Courier Forschungsinstitut Senckenberg 148: 53-153.

Koskinen MT, Ranta E, Piironen J, Veselov A, Titov S, Haugen $\mathrm{TO}$ et al (2000). Genetic lineages and postglacial colonization of grayling (Thymallus thymallus, Salmonidae) in Europe, as revealed by mitochondrial DNA analyses. Molec Ecol 9: 1609-1624.

Lessios HA (1992). Testing electrophoretic data for agreement with Hardy-Weinberg expectations. Mar Biol 112: 517-523.

Mantel N (1967). The detection of disease clustering and a generalized regression approach. Cancer Res 27: 392-403.

Nei M (1978). Estimation of average heterozygosity and genetic distance for small numbers of individuals. Genetics 89: 583-590.

Nei M, Chesser RK (1983). Estimation of fixation indices and gene diversities. Ann Hum Genet 47: 253-259.

Nesbo CL, Fossheim T, Vollestad LA, Jakobsen KS (1999). Genetic divergence and phylogeographic relationships among European perch (Perca fluviatilis) populations reflect glacial refugia and postglacial colonization. Molec Ecol 8: 1387-1404.

Reinig WF (1937). Die Holarktis. Fischer: Jena.

Reinig WF (1938). Elimination und Selektion. Fischer: Jena.

Rensch B (1939). Typen der Artbildung. Biol Rev (Cambr.) 14: 180-222.

Riffel M, Storch V, Schreiber A (1995). Allozyme variability of brown trout (Salmo trutta L) populations across the RhenanoDanubian watershed in southwest Germany. Heredity 74: 241-249.

Riffel M, Schreiber A (1995). Coarse-grained population structure in Central European sculpin (Cottus gobio L.): secondary contact or ongoing genetic drift? Z zool Syst Evolutionsforsch 33: $173-184$.

Rohlf FJ (1998). NTSYS/PC. Numerical taxonomy and multivariate analysis system, version 2.02f. Exeter Software: Setauket (New York).

Schreiber A, Engelhorn R (1998). Population genetics of a cyclostome species pair, river lamprey (Lampetra fluviatilis L) and brook lamprey (L. planeri Bloch). Z zool Syst Evolutionsforsch 36: 85-99.

Schreiber A, Eisinger M, Rumohr H, Storch V (1996). Icy heritage: ecological evolution of the postglacial Baltic Sea reflected in the allozymes of a living fossil, the priapulid Halicryptus spinulosus. Mar Biol 125: 671-685. 
Schreiber A, Engelhorn R, Riffel M (1998). Auswirkungen der Flußgeschichte von Rhein, Neckar, Doubs und Donau auf die Populationsgenetik von Groppen und Bachneunaugen. Verh dt ichthyol Ges 1: 185-202.

Schreiber A (Submitted). Genetic population structure of the stone loach (Barbatula barbatula) in the Rhine and Danube drainages. I Fish Biol.

Schreiber A (Submitted). Population genetic cohesion of disjunct populations of soufie (Leuciscus souffia) in the Rhine system.

Siebold C Th E von (1863). Die Süßwasserfische von Mitteleuropa. Engelmann: Leipzig.

Sokal RR (1979). Testing statistical significance of geographic variation patterns. Syst Zool 28: 227-232.

Thienemann A (1941). Die Süßwasserfische Deutschlands. Eine tiergeographische Skizze. In: Demoll R, Maier HN (eds) Hand-

buch der Binnenfischerei Mitteleuropas, III A/1, Schweizerbart: Stuttgart, pp 1-32.

Thienemann A (1950). Verbreitungsgeschichte der Süßwassertierwelt Europas. Schweizerbart: Stuttgart.

Torke W (1998). Fische aus jungpleistozänen und holozänen Siedlungsplätzen in Baden-Württemberg. Jh Ges Naturkunde Württemberg 154: 231-259.

Wanzenböck J, Kovacek H, Herzig-Straschil B (1869). Zum Vorkommen der Gründlinge im Osterreichischen Donauraum. Österreichs Fischerei 42: 118-128.

Workman PL, Niswander JD (1970). Population studies on southwestern Indian tribes. Am J Hum Genet 22: 24-49.

Wright S (1951). The genetical structure of populations. Ann Eugen 15: 323-354.

\section{Appendix}

Allele frequencies of polymorphic enzymes in population samples of Gobio gobio from the Rhine and the Danube river systems. The population samples are defined in Table 1, and the loci in Table 2

\begin{tabular}{|c|c|c|c|c|c|c|c|c|c|c|c|c|c|c|c|}
\hline \multirow{2}{*}{$\begin{array}{l}\text { Loci } \\
\text { Alleles }\end{array}$} & \multicolumn{4}{|c|}{$G p i-1^{*}$} & \multicolumn{2}{|c|}{$G p i-2^{*}$} & \multicolumn{2}{|c|}{ Pgm-2* } & \multicolumn{2}{|c|}{$L d h-1^{*}$} & \multicolumn{2}{|c|}{$\operatorname{Sod}^{*}$} & \multicolumn{2}{|c|}{$D i a^{*}$} & \\
\hline & 100 & 75 & 140 & 170 & 100 & 110 & 100 & 80 & 100 & 90 & 100 & 30 & 100 & 110 & \\
\hline \multicolumn{16}{|c|}{ Population sample } \\
\hline RHE & 1.000 & - & - & - & 1.000 & - & 0.725 & 0.275 & 1.000 & - & 0.865 & 0.135 & 0.955 & 0.045 & \\
\hline IST & 1.000 & - & - & - & 1.000 & - & 0.600 & 0.400 & 1.000 & - & 1.000 & - & 0.950 & 0.050 & \\
\hline RIE & 1.000 & - & - & - & 0.970 & 0.030 & 0.735 & 0.265 & 1.000 & - & 1.000 & - & 1.000 & - & \\
\hline WES & 1.000 & - & - & - & 1.000 & - & 0.930 & 0.070 & 1.000 & - & 1.000 & - & 1.000 & - & \\
\hline NET & 0.980 & 0.020 & - & - & 1.000 & - & 0.550 & 0.450 & 1.000 & - & 1.000 & - & 1.000 & - & \\
\hline STU & 0.930 & - & 0.070 & - & 1.000 & - & 0.680 & 0.320 & 1.000 & - & 1.000 & - & 1.000 & - & \\
\hline ROT & 0.955 & - & 0.045 & - & 1.000 & - & 1.000 & - & 1.000 & - & 1.000 & - & 1.000 & - & \\
\hline MUR & 1.000 & - & - & - & 1.000 & - & 0.735 & 0.265 & 1.000 & - & 1.000 & - & 1.000 & - & \\
\hline $\mathrm{ZAB}$ & 1.000 & - & - & - & 1.000 & - & 0.785 & 0.215 & 1.000 & - & 1.000 & - & 1.000 & - & \\
\hline BÜH & 1.000 & - & - & - & 1.000 & - & 0.915 & 0.085 & 1.000 & - & 1.000 & - & 1.000 & - & \\
\hline GER & 1.000 & - & - & - & 0.830 & 0.170 & 0.835 & 0.165 & 1.000 & - & 1.000 & - & 0.975 & 0.025 & \\
\hline $\mathrm{BEU}$ & 0.750 & - & 0.250 & - & 0.975 & 0.025 & 0.825 & 0.175 & 0.925 & 0.075 & 0.975 & 0.025 & 1.000 & - & \\
\hline NEU & 0.375 & - & 0.625 & - & 1.000 & - & 1.000 & - & 1.000 & - & 1.000 & - & 1.000 & - & \\
\hline WEN & 0.800 & - & 0.125 & 0.075 & 0.975 & 0.025 & 0.725 & 0.275 & 1.000 & - & 1.000 & - & 1.000 & - & \\
\hline ISA & 0.625 & - & 0.375 & - & 1.000 & - & 0.875 & 0.125 & 1.000 & - & 0.750 & 0.250 & 1.000 & - & \\
\hline OES & 1.000 & - & - & - & 1.000 & - & 1.000 & - & 1.000 & - & 1.000 & - & 1.000 & - & \\
\hline ROS & 1.000 & - & - & - & 1.000 & - & 1.000 & - & 1.000 & - & 1.000 & - & 1.000 & - & \\
\hline \multirow{2}{*}{$\begin{array}{l}\text { Loci } \\
\text { Alleles }\end{array}$} & \multicolumn{4}{|c|}{ Aat-2* } & \multicolumn{3}{|c|}{ Aat-3* } & \multicolumn{2}{|c|}{$A d a^{*}$} & \multicolumn{2}{|c|}{$M d h-3^{*}$} & \multicolumn{2}{|c|}{$M d h-4^{*}$} & \multicolumn{2}{|c|}{$M p i^{*}$} \\
\hline & -100 & -80 & -140 & 75 & 100 & 80 & 110 & 100 & 125 & 100 & 70 & 100 & 90 & 100 & 110 \\
\hline \multicolumn{16}{|c|}{ Population sample } \\
\hline RHE & 1.000 & - & - & - & 1.000 & - & - & 1.000 & - & 1.000 & - & 1.000 & - & 1.000 & - \\
\hline IST & 1.000 & - & - & - & 0.950 & 0.050 & - & 1.000 & - & 1.000 & - & 1.000 & - & 1.000 & - \\
\hline RIE & 0.975 & 0.025 & - & - & 1.000 & - & - & 1.000 & - & 0.975 & 0.025 & 1.000 & - & 1.000 & - \\
\hline WES & 0.860 & 0.070 & - & 0.070 & 1.000 & - & - & 1.000 & - & 1.000 & - & 1.000 & - & 1.000 & - \\
\hline NET & 0.885 & - & 0.100 & 0.015 & 1.000 & - & - & 1.000 & - & 1.000 & - & 1.000 & - & 1.000 & - \\
\hline STU & 0.885 & - & 0.115 & - & 1.000 & - & - & 1.000 & - & 1.000 & - & 1.000 & - & 1.000 & - \\
\hline ROT & 0.775 & - & 0.225 & - & 1.000 & - & - & 1.000 & - & 1.000 & - & 1.000 & - & 1.000 & - \\
\hline MUR & 0.815 & - & 0.185 & - & 1.000 & - & - & 1.000 & - & 1.000 & - & 1.000 & - & 1.000 & - \\
\hline $\mathrm{ZAB}$ & 0.950 & 0.050 & - & - & 0.975 & - & 0.025 & 1.000 & - & 1.000 & - & 0.975 & 0.025 & 1.000 & - \\
\hline BÜH & 1.000 & - & - & - & 1.000 & - & - & 1.000 & - & 1.000 & - & 1.000 & - & 1.000 & - \\
\hline GER & 1.000 & - & - & - & 1.000 & - & - & 1.000 & - & 1.000 & - & 1.000 & - & 1.000 & - \\
\hline BEU & 1.000 & - & - & - & 1.000 & - & - & 0.800 & 0.200 & 1.000 & - & 0.975 & 0.025 & 0.925 & 0.075 \\
\hline NEU & 0.940 & - & 0.060 & - & 1.000 & - & - & 0.750 & 0.250 & 1.000 & - & 1.000 & - & 1.000 & - \\
\hline WEN & 0.470 & - & 0.530 & - & 1.000 & - & - & 0.780 & 0.220 & 1.000 & - & 1.000 & - & 0.935 & 0.065 \\
\hline ISA & 1.000 & - & - & - & 1.000 & - & - & 0.625 & 0.375 & 1.000 & - & 1.000 & - & 1.000 & - \\
\hline OES & 1.000 & - & - & - & 1.000 & - & - & 1.000 & - & 1.000 & - & 1.000 & - & 1.000 & - \\
\hline ROS & 1.000 & - & - & - & 1.000 & - & - & 1.000 & - & 1.000 & - & 1.000 & - & 1.000 & - \\
\hline
\end{tabular}


Appendix Continued

\begin{tabular}{|c|c|c|c|c|c|c|c|c|c|c|c|c|c|}
\hline \multirow{2}{*}{$\begin{array}{l}\text { Loci } \\
\text { Alleles }\end{array}$} & \multicolumn{2}{|l|}{$\operatorname{Pg} d^{*}$} & \multicolumn{3}{|l|}{$C k-1^{*}$} & \multicolumn{2}{|l|}{$C k-2^{*}$} & \multicolumn{2}{|l|}{$C k-3^{*}$} & \multicolumn{4}{|l|}{$\mathrm{Me}-2^{*}$} \\
\hline & 100 & 70 & 100 & 125 & 160 & 100 & 125 & 100 & 108 & 100 & 60 & 115 & 160 \\
\hline \multicolumn{14}{|c|}{ Population sample } \\
\hline RHE & 0.545 & 0.455 & 1.000 & - & - & 1.000 & - & 1.000 & - & 0.955 & - & 0.045 & - \\
\hline IST & 0.750 & 0.250 & 1.000 & - & - & 1.000 & - & 1.000 & - & 0.500 & 0.500 & - & - \\
\hline RIE & 0.630 & 0.370 & 1.000 & - & - & 0.815 & 0.185 & 1.000 & - & 0.710 & - & 0.290 & - \\
\hline WES & 0.715 & 0.285 & 1.000 & - & - & 0.785 & 0.215 & 1.000 & - & 0.785 & - & 0.215 & - \\
\hline NET & 0.465 & 0.535 & 1.000 & - & - & 1.000 & - & 1.000 & - & 0.575 & 0.075 & 0.350 & - \\
\hline STU & 0.425 & 0.575 & 1.000 & - & - & 1.000 & - & 0.930 & 0.070 & 0.960 & 0.040 & - & - \\
\hline ROT & 0.590 & 0.410 & 0.820 & 0.180 & - & 0.910 & 0.090 & 1.000 & - & 0.865 & - & 0.135 & - \\
\hline MUR & 0.515 & 0.485 & 1.000 & - & - & 1.000 & - & 1.000 & - & 0.845 & - & 0.143 & 0.010 \\
\hline ZAB & 0.595 & 0.405 & 1.000 & - & - & 0.740 & 0.260 & 1.000 & - & 0.810 & - & 0.190 & - \\
\hline BÜH & 0.835 & 0.165 & 1.000 & - & - & 1.000 & - & 1.000 & - & 1.000 & - & - & - \\
\hline GER & 0.880 & 0.120 & 1.000 & - & - & 1.000 & - & 1.000 & - & 0.665 & - & 0.335 & - \\
\hline $\mathrm{BEU}$ & 0.450 & 0.550 & 0.420 & 0.580 & - & 1.000 & - & 1.000 & - & 0.725 & 0.125 & 0.150 & - \\
\hline NEU & 0.500 & 0.500 & 0.875 & 0.125 & - & 1.000 & - & 1.000 & - & 0.685 & 0.190 & 0.125 & - \\
\hline WEN & 0.665 & 0.335 & 1.000 & - & - & 1.000 & - & 1.000 & - & 0.595 & 0.185 & 0.220 & - \\
\hline ISA & 0.560 & 0.440 & 0.430 & 0.355 & 0.215 & 1.000 & - & 1.000 & - & 0.690 & 0.245 & 0.065 & - \\
\hline OES & 1.000 & - & 1.000 & - & - & 1.000 & - & 1.000 & - & 0.735 & 0.265 & - & - \\
\hline ROS & 0.595 & 0.405 & 0.900 & 0.100 & - & 1.000 & - & 1.000 & - & 0.710 & 0.290 & - & - \\
\hline
\end{tabular}

